\title{
Characterization of organic carbon in black shales of the Kachchh basin, Gujarat, India
}

\author{
Hema Srivastava ${ }^{1}$, Ajoy K Bhaumik ${ }^{1, *}$, Devleena Tiwari ${ }^{2}$, \\ SARAdA P MOHANTY ${ }^{1}$ and DatTatray J PATIL ${ }^{2}$ \\ ${ }^{1}$ Department of Applied Geology, Indian Institute of Technology (Indian School of Mines), \\ Dhanbad 826004 , India. \\ ${ }^{2}$ Petroleum Geochemistry and Microbiology Group, National Geophysical Research Institute, \\ Hyderabad 500 007, India. \\ ${ }^{*}$ Corresponding author.e-mail: ajoyism@gmail.com
}

MS received 22 September 2017; revised 9 January 2018; accepted 28 January 2018;

published online 18 August 2018

Thirty-three black shale samples from four locations on the onland Kachchh basin, western India were analyzed to characterize organic carbon (OC), thermal maturity and to determine the hydrocarbon potential of the basin. Upper Jurassic black shales from the Jhuran Formation (Dhonsa and Kodki areas) are characterized by the presence of chlorite, halloysite, high $T_{\max }$, low $\mathrm{OC}$, low hydrogen index and high oxygen index. These parameters indicate the OC as type IV kerogen, formed in a marine environment. The rocks attained thermal maturity possibly during Deccan volcanism. Early Eocene samples of the Naredi Formation (Naliya-Narayan Sarovar Road (NNSR) and the Matanomadh areas) are rich in TOC, smectite, chlorite and framboidal pyrite, but have low $T_{\max }$. These indicate deposition of sediments in a reducing condition, probably in a lagoonal/marsh/swamp environment. Organic carbon of the Naredi Formation of NNSR may be considered as immature type III to IV kerogen, prone to generate coal. Core samples from the Naredi Formation of the Matanomadh area show two fold distribution in terms of kerogen. Organic carbon of the upper section is immature type III to IV kerogen, but the lower section has type II to III kerogen having potential to generate oil and gas after attaining appropriate thermal maturity.

Keywords. Black shale; organic carbon; Rock-Eval pyrolysis; thermal maturity; Kachchh basin.

\section{Introduction}

Black shales in stratigraphic records are considered as organic carbon rich sedimentary units, which are deposited in unique paleoenvironmental condition and are considered to be potential for hydrocarbon generation. These shales are described as dark coloured mud rocks containing a mixture of clay minerals, quartz silts and organic matter. The organic carbon in these rocks generally ranges between 1 and $30 \%$ (Tourtelot 1979; Weissert 1981). The concentration of the organic matter within shale or mud gets enhanced during the period of aquatic anoxia. Preservations of organic carbons are mainly controlled by the clay mineralogy and availability of mineral surface area along with other depositional parameters (e.g., low oxygen content of the water column and pore water having $<0.2 \mathrm{ml} / \mathrm{l}$ water, restriction in water circulation, lack of bioturbation, deposition 


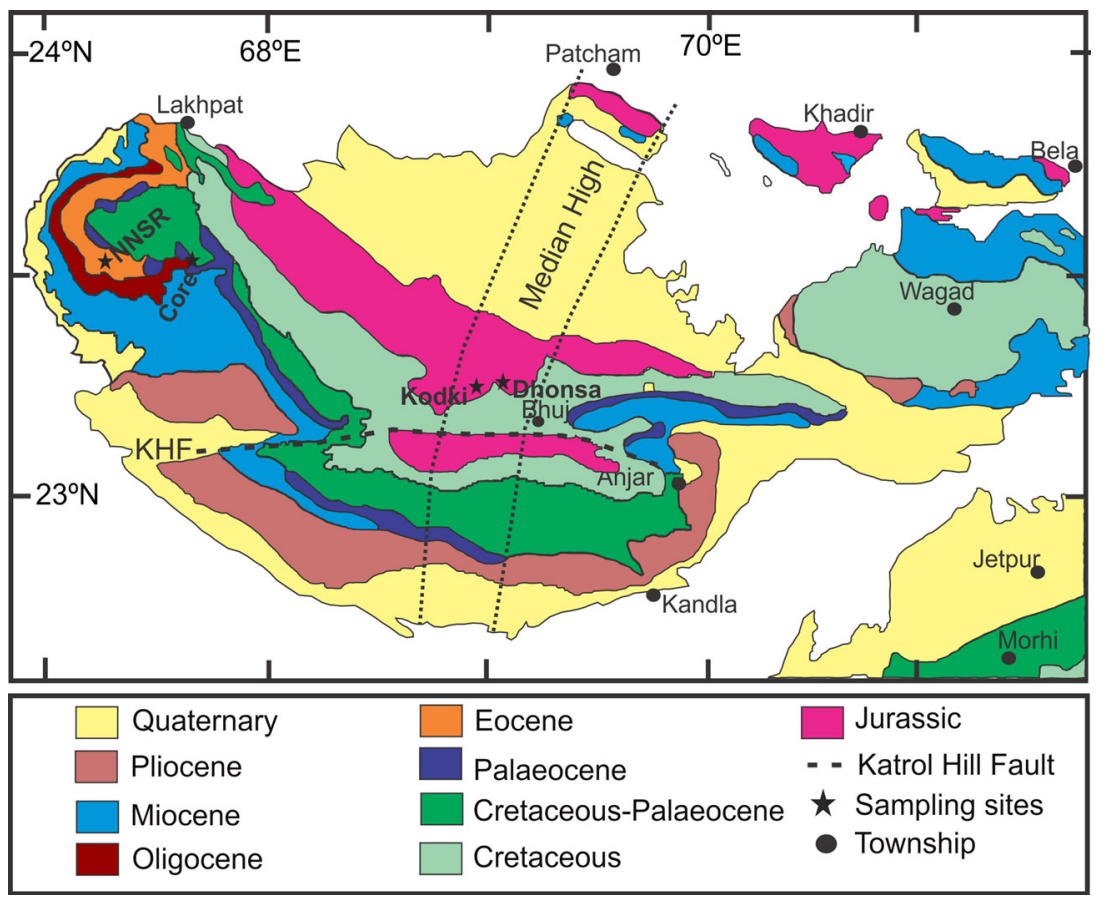

Figure 1. Location map of the studied sites in the Kachchh district, Gujarat, India (redrawn and modified after Mishra et al. 2014). Solid black stars represent sample collection sites.

of very fine-grained sediment particles of $<2 \mu$, and an optimum sedimentation rate) (Kennedy et al. 2002). Black shale bears great economic interest as the main source rock of hydrocarbon generation. Estimate suggests that more than $90 \%$ of global recoverable oil and gas reserves were generated from black shale (Klemme and Ulmishek 1991). The quality and quantity of organic matter play important role in the generation of hydrocarbon. Source rock characterization using organic geochemical technique (Rock-Eval pyrolyser) is widely used to evaluate the quality, quantity, hydrocarbon generation potential and thermal maturity of organic carbon (Espitalié et al. 1986; Peters and Cassa 1994; Banerjee et al. 2006; Mani et al. 2014, 2015; Bourah and Ganapathi 2015). The total organic carbon (TOC) and biomarker studies are also helpful to characterize the type and maturity of organic matter in black shales and other organic carbon rich rocks (Banerjee et al. 2006; Sivan et al. 2008; Arora et al. 2015, 2017; Bourah and Ganapathi 2015; Mani et al. 2017).

Black shales have been reported from several sedimentary basins of India, which include the Paleoproterozoic Cuddapah basin (Manikyamba et al. 2008), Mesoproterozoic to Neoproterozoic Vindhyan basin (Banerjee et al. 2006; Paikaray et al. 2008; Bhaskar 2013), Permian Gondwana basin of the Krishna-Godavari valley (Rao 2001;
Bhaskar 2013), Permian to Mesozoic Gondwana basins of the Damodar Valley (Bhaskar 2013; Bourah and Ganapathi 2015; Mani et al. 2015; Tewari et al. 2016), Permian-Triassic basins in the Himalayan Region (Mani et al. 2014), Paleogene Cambay basin (Banerjee and Rao 1993; Bhaskar 2013), Paleogene of the Cauvery basin (Chandra et al. 1991; Bhaskar 2013) and the MesozoicPaleogene rocks of the Kachchh basin (Dutta et al. 2011; Sahay 2011; Mishra et al. 2014; Arora et al. 2015, 2017). Thick and well-developed organic-rich black shales constitute distinct stratigraphic units of the onland Kachchh basin of western India (figure 1). The Kachchh basin has been classified as a category II basin (identified prospectivity) owing to its favourable depositional and thermal history for hydrocarbon generation (DGH 2017). The Cambay basin along the eastern and southeastern side of the Kachchh basin is a proven petroliferous basin, having the Cambay shale of Eocene age as the source rock. The Kachchh basin is flanked by the hydrocarbon-producing Mumbai offshore basin in the south, and the South Indus basin of Pakistan in the north. Oil and gas shows have been observed in several wells drilled on offshore and onshore Kachchh basin (Patil et al. 2013). Characterization of black shales from the northern and southern onland part of this basin were previously done from the Jhuran Formation in and around 
Khari River channel, Rudramata bridge, and Zara, Dharang and Jhumara, Palara and Ler villages (Arora et al. 2015, 2017). Similar studies have been carried on the black shales of the Naredi Formation from the Panandhro, Umarsar and Matanomadh lignite mines in this basin (Dutta et al. 2011; Sahay 2011; Mishra et al. 2014). In addition, it is important to note that sediments from upper Jurassic as well as Late Cretaceous to Eocene times contributed 25 and $2.8 \%$ of global hydrocarbons (oil and gas), respectively (Klemme and Ulmishek 1991).

Black shale samples of Jhuran and Naredi Formations have been collected from four new localities (Bhuj-Kodki Road, near Dhonsa village, Naliya-Narayan Sarovar Road and Matanomadh), which are situated within the central part of the basin, for the present study. Thus, organic carbon within these black shales needs to be characterized in terms of quantity, quality, thermal maturity and hydrocarbon generation potentiality. The present research work deals with the geochemical (RockEval pyrolysis) and SEM study on 33 samples collected from these locations.

\section{Locations and geological settings}

The Kachchh basin was developed at the boundary of the African and Indian blocks during the breakup of the Gondwana land at $\sim 170 \mathrm{Ma}$ (Besse and Courtillot 1988). This breakup gave rise to the development of different horsts and grabens forming the sites for deposition of the Jurassic sediments (Biswas 2016). The basin had an eruption of the Deccan volcanics during Late Cretaceous-Early Paleocene. The basin had further subsidence and deposition of Cenozoic sediments. The stratigraphic units mapped in the basin by different early workers are presented in table 1.

The samples were collected from four different zones in the western part of the Kachchh district, Gujarat, India. These areas are close to the Dhonsa village, on Bhuj-Kodki Road, and between Javda and Harudi/Baranda villages on Naliya-Narayan Sarovar road (figure 1). Further, core samples were collected from an area close to the Matanomadh lignite mine (figure 1). The first location is along a recently exposed road cutting section $\left(23^{\circ} 19^{\prime} 35.44^{\prime \prime} \mathrm{N} ; 69^{\circ} 37^{\prime} 25.96^{\prime \prime} \mathrm{E}\right) 1 \mathrm{~km}$ before the Dhonsa village (hereafter termed as Dhonsa). This section consists of alternate bands of finely laminated black shales and fine-grained light pink coloured sandstones (figure 2). The rocks of this section belong to the Jhuran Formation (Katrol Series) having upper Jurassic age (Biswas 1977). The second location is on another fresh road cutting $\left(23^{\circ} 14^{\prime} 38.05^{\prime \prime} \mathrm{N} ; 69^{\circ} 34^{\prime} 57.47^{\prime \prime} \mathrm{E}\right)$ along the Bhuj-Kodki Road, which is observed around 2.5 $\mathrm{km}$ from the Kodki village (hereafter mentioned as Kodki). This section also comprises alternate bands of fine grained pink coloured sandstone and black shales (figure 3) of the Jhuran Formation of upper Jurassic age (Biswas 1977). The third sampling location is situated along the left side of the Naliya-Narayan Sarovar road (hereafter termed as NNSR), between Javda and Harudi/Baranda villages $\left(23^{\circ} 31^{\prime} 28.29^{\prime \prime} \mathrm{N} ; 68^{\circ} 41^{\prime} 8.35^{\prime \prime} \mathrm{E}\right.$, figure 1$)$. This area consists of several humps of gypsiferous shale of the Naredi Formation of Early Eocene age (Biswas 1992). The shale unit contains abundant larger foraminifera (Assilina). Samples were collected from a small section at the basal part of one hump of black shale with glittering lustre similar to coal (figure 4).

Core samples were collected from a single drill hole (Borehole number KAM-164 of Gujarat Mineral Development Corporation Ltd.; hereafter designated as core) near the Matanomadh lignite mine area (figure 1). The core penetrated to a depth of $94 \mathrm{~m}$, extending up to the Deccan basalt of upper Cretaceous age. The Paleocene sedimentary sequence is not developed in this zone. Samples were collected from Early Eocene sediments (at 44-74 m depth), which belong to the Naredi Formation (Biswas 1992; Merh 1995) and consist of thick alternate bands of black shale and lignite beds.

\section{Materials and methods}

A total of 33 samples ( 8 from Dhonsa, 4 from Kodki, 3 from NNSR and 18 from core, respectively) were studied for their bulk organic properties using Rock-Eval 6 Pyrolyser. The samples were pyrolized in Rock-Eval 6 (Turbo Version) unit in CSIR - National Geophysical Research Institute, Hyderabad. The instrument was calibrated using IFP standard 16,000 $\left(T_{\max }=416^{\circ} \mathrm{C}\right.$ and $\mathrm{S}_{2}=12.43 \mathrm{mg} / \mathrm{g}$ rock) after getting the stable signals from the detectors. Approximately 60$70 \mathrm{mg}$ of finely homogenized powdered samples were weighed in pre-oxidized crucibles and were pyrolized in an inert atmosphere using nitrogen gas under analysis mode using bulk rock method and basic cycle of Rock-Eval 6 (Mani et al. 2014). 
Table 1. Mesozoic and Cenozoic stratigraphy of the Kachchh basin (after Biswas 2016). Solid black stars indicate stratigraphic positions of samples. (a) Stratigraphy of the Dhonsa-Kodki areas, and (b) stratigraphy of the NNSR and Matanomadh areas.

(a)

\begin{tabular}{|c|c|c|c|}
\hline \multicolumn{2}{|l|}{ AGE } & FORMATION & LITHOLOGY \\
\hline \multicolumn{2}{|c|}{$\begin{array}{c}\text { LATE CRETACEOUS } \\
\text { TO } \\
\text { PALEOCENE }\end{array}$} & \multirow{2}{*}{$\begin{array}{c}\text { DECCAN } \\
\text { TRAP } \\
500 \mathrm{~m} \\
\\
\\
\text { Unconformity }\end{array}$} & Basalt flow \\
\hline $\begin{array}{c}\text { ALBIAN } \\
\text { TO } \\
\text { NEOCOMIAN }\end{array}$ & 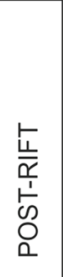 & & $\begin{array}{c}\text { Mainly } \\
\text { sandstones } \\
\text { with } \\
\text { ferruginous } \\
\text { bands and } \\
\text { shale } \\
\text { interbeds with } \\
\text { plant fossils }\end{array}$ \\
\hline $\begin{array}{c}\text { TITHONIAN } \\
\text { TO } \\
\text { MID-OXFORDIAN }\end{array}$ & 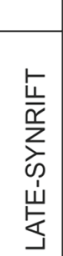 & 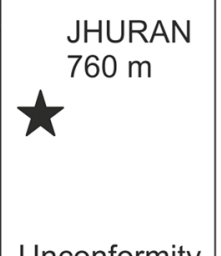 & $\begin{array}{l}\text { Sandstones with } \\
\text { calcareous bands } \\
\text { and shale (delta } \\
\text { front), middle part } \\
\text { mainly shale } \\
\text { (prodelta) }\end{array}$ \\
\hline $\begin{array}{c}\text { EARLY } \\
\text { OXFORDIAN }\end{array}$ & $\sum_{0}^{x}$ & $\begin{array}{l}\text { JUMARA } \\
275 \mathrm{~m}\end{array}$ & $\begin{array}{l}\text { Mainly shale } \\
\text { with thin } \\
\text { limestone } \\
\text { beds, oolite } \\
\text { bands on top }\end{array}$ \\
\hline $\begin{array}{l}\text { BATHONIAN } \\
\text { TO } \\
\text { BAJOCIAN }\end{array}$ & $\sum_{\substack{\frac{1}{\alpha} \\
\frac{\bar{\alpha}}{c}}}$ & $\begin{array}{l}\text { JHURIO } \\
290 \mathrm{~m}^{+}\end{array}$ & $\begin{array}{l}\text { Interbedded } \\
\text { shale and } \\
\text { limestone } \\
\text { with golden } \\
\text { oolites. } \\
\text { Upper part: } \\
\text { bedded } \\
\text { limestone }\end{array}$ \\
\hline PRECAMBRIAN & & Basement & Not exposed \\
\hline
\end{tabular}

(b)

\begin{tabular}{|c|c|c|c|}
\hline AGE & STAGE & FORMATION & LITHOLOGY \\
\hline 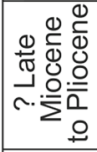 & $\begin{array}{l}\text { Kankawatian } \\
\text { Super-stage }\end{array}$ & SANDHAN 249 m+ & $\begin{array}{c}\text { Sandstone, minor } \\
\text { limestone and shale } \\
\text { Upper part calc. } \\
\text { concretionary }\end{array}$ \\
\hline 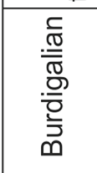 & VINJHANIAN & CHHASRA $16 \mathrm{~m}$ & $\begin{array}{l}\text { Upper:silty shale } \\
\text { Lower:shale/ } \\
\text { limestone } \\
\text { highly fossiliferous }\end{array}$ \\
\hline 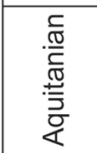 & AIDAIAN & $\begin{array}{c}\text { KHARI NADI } \\
65 \mathrm{~m}\end{array}$ & $\begin{array}{l}\text { Variegated } \\
\text { siltstone and } \\
\text { sandstones }\end{array}$ \\
\hline $\begin{array}{l}\frac{\pi}{N} \\
\frac{\pi}{\pi} \\
\frac{\pi}{U} \\
\end{array}$ & WAIORIAN & \multirow[b]{2}{*}{$\begin{array}{l}\text { MANYARA FORT } \\
35 \mathrm{~m}\end{array}$} & \multirow{2}{*}{$\begin{array}{l}\text { Upper:Foram. } \\
\text { limestone/oolite } \\
\text { sandstone, Middle: } \\
\text { limestone with coral } \\
\text { biotherm, Lower: lumpy } \\
\text { claystone, glauc. } \\
\text { gypseous shale }\end{array}$} \\
\hline 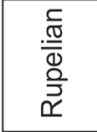 & RAMANIAN & & \\
\hline $\begin{array}{c}\text { Priabo } \\
\text { nian }\end{array}$ & HIATUS & \multicolumn{2}{|c|}{---Paraconformity--- } \\
\hline 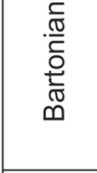 & RAKHADIAN & $\begin{array}{l}\text { FULRA } \\
\text { LIMESTONE } \\
60 \mathrm{~m}\end{array}$ & $\begin{array}{l}\text { Dense } \\
\text { foraminiferal } \\
\text { limestone }\end{array}$ \\
\hline \multirow[t]{2}{*}{ 空 } & BABIAN & HARUDI $14 \mathrm{~m}$ & $\begin{array}{l}\text { Claystone/ } \\
\text { limestone, } \\
\text { coquina highly } \\
\text { fossiliferous }\end{array}$ \\
\hline & Hiatus & \multicolumn{2}{|c|}{ 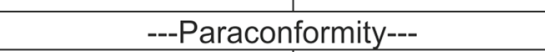 } \\
\hline $\begin{array}{l}\frac{.}{0} \\
\frac{.0}{0} \\
\frac{0}{x}\end{array}$ & KAKDIAN & \multirow{3}{*}{$\begin{array}{c}\text { NAREDI } 40 \mathrm{~m} \\
\text { } \\
\text {--Disconformity--- } \\
\text { MATANOMADH } \\
49 \mathrm{~m} \\
\text {---Disconformity--- } \\
\text { DECCAN TRAP }\end{array}$} & $\begin{array}{l}\text { Upper: ferruginous } \\
\text { claystone. Middle: } \\
\text { Assilina limestone. } \\
\text { Lower:glauconitic } \\
\text { gypseous shale }\end{array}$ \\
\hline 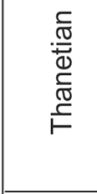 & MADHIAN & & $\begin{array}{c}\text { Laterites \& } \\
\text { volcanoclastics: } \\
\text { tuffaceous shales \& } \\
\text { sandstones } \\
\text { bentonite } \\
\text { clay }\end{array}$ \\
\hline Mac & $\begin{array}{l}\text { astrichtian to } \\
\text { Danian }\end{array}$ & & Basalt \\
\hline
\end{tabular}

The pyrolysis oven was programmed with an initial temperature at $300^{\circ} \mathrm{C}$, with stepwise increase to $650^{\circ} \mathrm{C}$ at an increment rate of $25^{\circ} \mathrm{C} / \mathrm{min}$. Released hydrocarbons were measured by Flame Ionization
Detector (FID). The samples were then oxidized in an oxidation oven. Temperature of the oxidation oven was increased stepwise from 300 to $850^{\circ} \mathrm{C}$ with an increment rate of $20^{\circ} \mathrm{C} / \mathrm{min}$. 


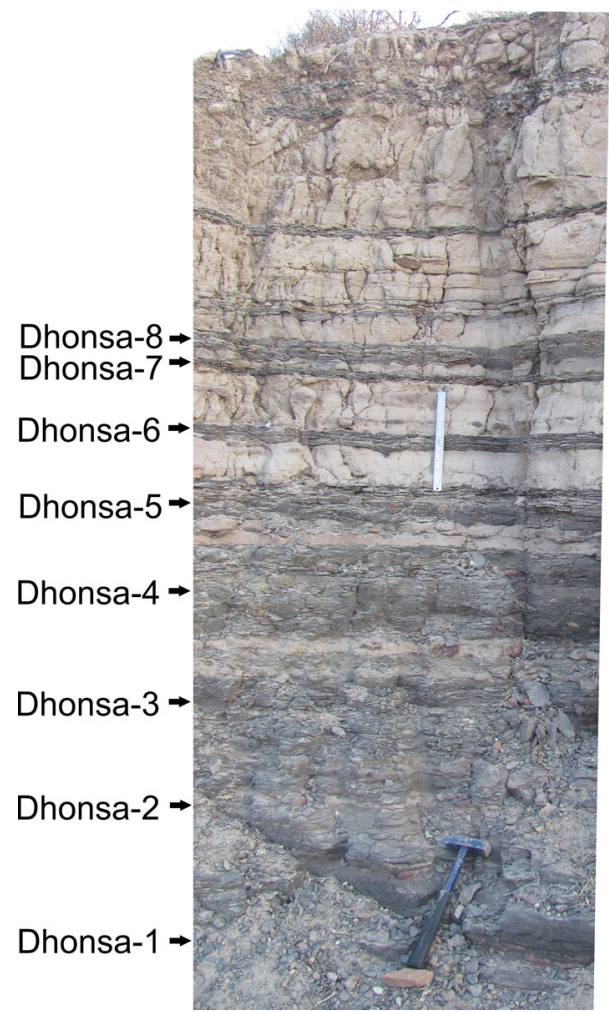

Figure 2. Photograph of the road section near Dhonsa village. Arrows indicate the positions of samples collected for this study. Length of the scale is $30.5 \mathrm{~cm}$.

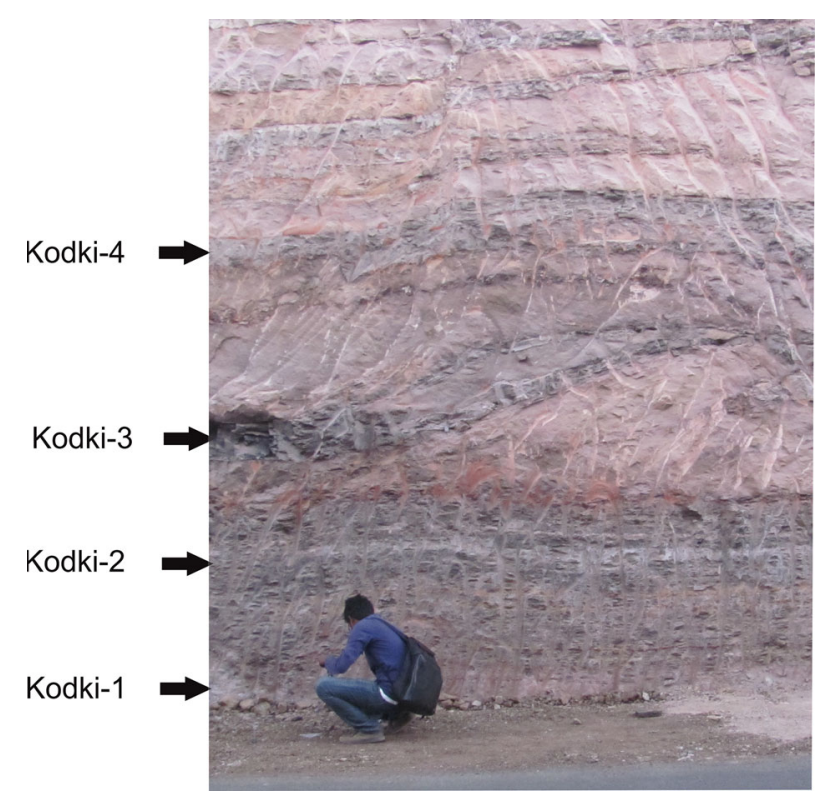

Figure 3. Photograph of the Kodki road section. Arrows indicate sampling positions.

The SEM observations were undertaken at Central Research Facilities, Indian Institute of Technology (Indian School of Mines), Dhanbad using Zeiss Supra 55 FESEM instrument.

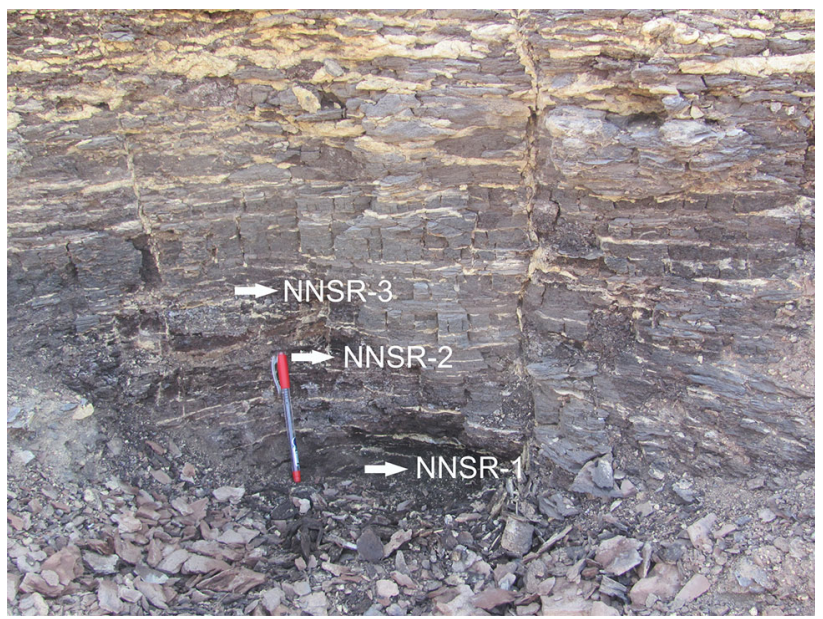

Figure 4. Photograph of the black shale-sampling site in NNSR. Arrows indicate sampling positions. Length of the pen is $14.5 \mathrm{~cm}$.

\section{Results}

SEM analyses of 12 selected samples show dominance of chlorite. However, smectite in samples of the Naredi Formation (NNSR) and halloysite in the Jhuran Formation (Kodki) are recorded along with chlorite (figure 5). Additionally, samples from NNSR and core contain numerous well-developed pyrite crystals (figure 5).

Rock-Eval pyrolysis was carried out to understand quantity, quality and thermal maturity of organic matter as well as hydrocarbon generation potential of the black shales. Different parameters obtained through the pyrolysis are presented in table 2. Surface samples from Dhonsa show very low to moderate TOC content ranging from 0.43 to $0.96 \%$. The $\mathrm{S}_{1}$ (thermo-vaporized free hydrocarbons) and $\mathrm{S}_{2}$ (hydrocarbons from cracking of organic matters) values are low (up to 0.02 and 0.15 $\mathrm{mg} \mathrm{HC} / \mathrm{g}$ rock) in these samples. The hydrogen index (HI) and oxygen index (OI) were calculated for each samples using the formula $\mathrm{HI}=$ $\left(100 \times \mathrm{S}_{2}\right) /$ TOC and OI $=\left(100 \times \mathrm{S}_{3}\right) /$ TOC, respectively (Lafargue et al. 1988; McCarthy et al. 2011; Mishra et al. 2014). The HI and OI lie between 8 $28 \mathrm{mg} \mathrm{HC} / \mathrm{g}$ TOC and 105-286 $\mathrm{mg} \mathrm{CO}_{2} / \mathrm{g}$ TOC, respectively. The $T_{\max }$ (temperature having highest yield of hydrocarbons generated by cracking of kerogen) values for these samples range between 440 and $607^{\circ} \mathrm{C}$. Mineral carbon contents of these samples are low and are within the range of 0.05 $0.19 \%$ (table 2). Surface samples of Kodki do not have any detectable values of $\mathrm{S}_{1}, \mathrm{~S}_{2}$ and $T_{\max }$. The TOC and mineral carbon content of these samples are also in lower end and range between 

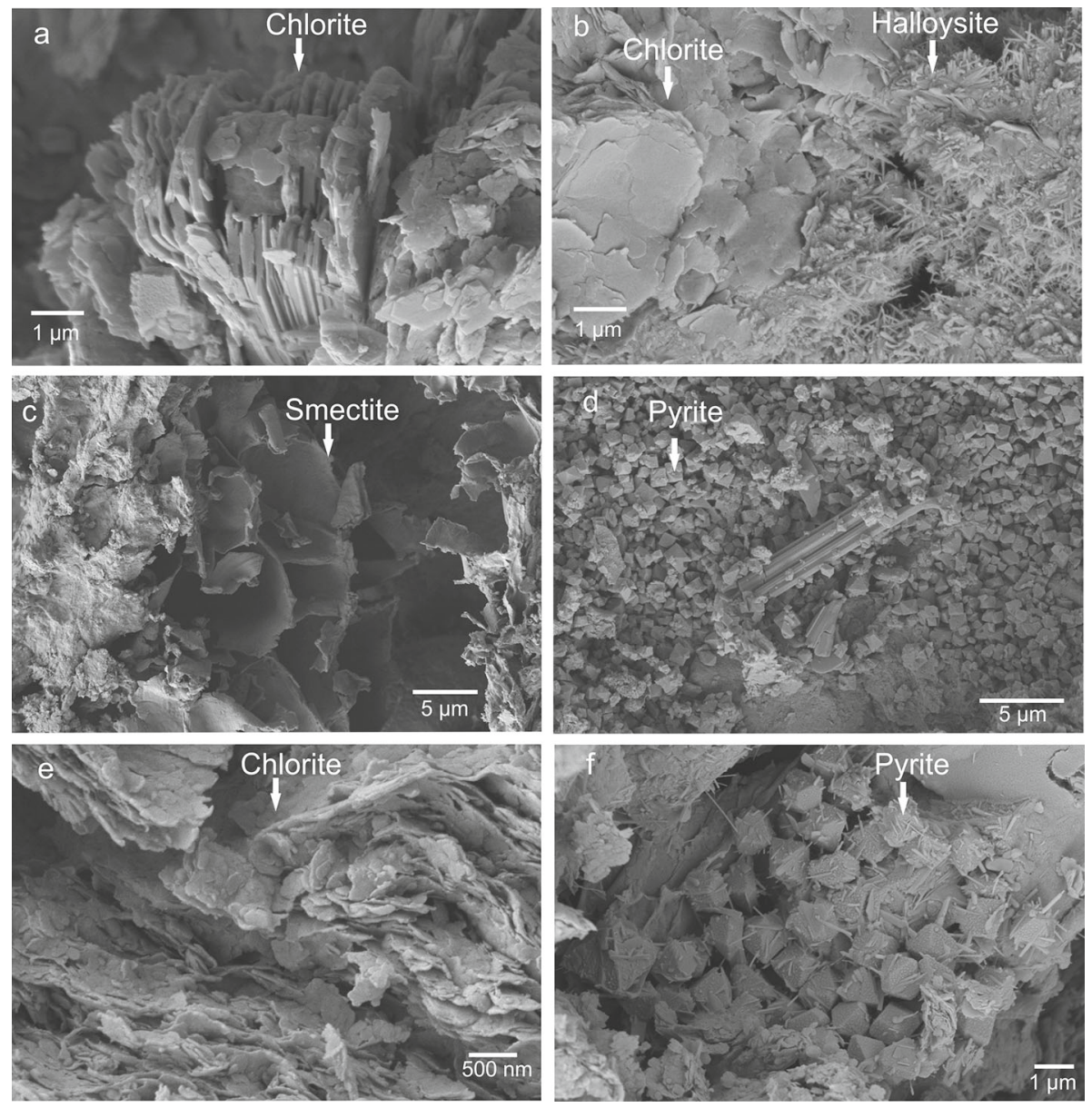

Figure 5. FESEM images of minerals present in black shales collected from different locations in this study: (a) chlorite in shale collected from Dhonsa, (b) chlorite and halloysite from Kodki, (c) smectite in NNSR, (d) pyrite crystals in NNSR, (e) chlorite in core samples, and (f) pyrite crystals in core samples.

$0.44-0.87 \%$ and $0.12-0.2 \%$, respectively (table 2 ). Surface samples from NNSR show $\mathrm{S}_{1}$ and $\mathrm{S}_{2}$ values ranging between $0.08-0.22$ and $0.04-24.89 \mathrm{mg}$ $\mathrm{HC} / \mathrm{g}$ rock, respectively. TOC values for these samples lie within $0.08-20.46 \%$. The HI and OI values are confined with the ranges $50-122 \mathrm{HC} / \mathrm{g}$ TOC and $81-525 \mathrm{CO}_{2} / \mathrm{g}$ TOC, respectively. Mineral carbon content lies within $0.03-0.94 \%$ (table 2). Core samples from the Matanomadh area are rich in TOC, which ranges between 3.01 and $27.2 \%$. The $\mathrm{S}_{1}$ and $\mathrm{S}_{2}$ values are ranging between $0.01-2.98$ and 2.36-107.88 mg HC/g rock, respectively. The $T_{\max }$ values for these samples lie within $394-431^{\circ} \mathrm{C}$. Mineral matters within these samples vary from 0.13 to $1.03 \%$ (table 2 ).

\section{Discussion}

\subsection{Organic carbon richness}

Organic carbon richness is an important factor for classifying the hydrocarbon generation potential of sediments. Sediments may be broadly subdivided into five groups based on organic carbon content. The hydrocarbon generation potential is considered poor where the TOC values lie within $0-0.5 \%$, fair where they are within $0.5-1 \%$, good for values within 1-2\%, very good for values within $2-4 \%$ and excellent where the values are $>4 \%$ (North 1985; McCarthy et al. 2011). Upper Jurassic black shale samples from the Jhuran Formation of Dhonsa and Kodki region have very low TOC concentration $(<1 \%$, table 2$)$. Thus, these black shales do not show characteristics of good source rock. The sediments in these areas are rich in chlorite along with some occurrence of halloysite (figure 5b). Platy mineral chlorite has large surface area, which might had greater capacity to retain organic carbon during the deposition of sediments (Kennedy et al. 2002). It has been observed that in TOC lean sediments, the mineral matrix with quartz, calcite, etc., may retain some of the $\mathrm{S}_{2}$ content and also catalyse the thermal decomposition of kerogen, altering the $\mathrm{S}_{2}$ 
Table 2. Rock-Eval pyrolysis data obtained from Jhuran black shales of Dhonsa, and Kodki areas as well as Naredi black shales of NNSR and core.

\begin{tabular}{|c|c|c|c|c|c|c|c|}
\hline Sample id & $\begin{array}{c}\mathrm{S}_{1} \\
(\mathrm{mg} / \mathrm{g} \text { rock })\end{array}$ & $\begin{array}{c}\mathrm{S}_{2} \\
(\mathrm{mg} / \mathrm{g} \text { rock })\end{array}$ & $\begin{array}{l}T_{\max } \\
\left({ }^{\circ} \mathrm{C}\right)\end{array}$ & $\begin{array}{c}\text { TOC } \\
(\%)\end{array}$ & $\mathrm{HI}$ & OI & $\begin{array}{c}\text { MINC } \\
(\%)\end{array}$ \\
\hline \multicolumn{8}{|c|}{ Jhuran Foundation, Age: Upper Jurassic (Kimmeridgian to Tithonian) } \\
\hline Dhonsa-1 & 0.02 & 0.15 & 607 & 0.54 & 28 & 107 & 0.05 \\
\hline Dhonsa-2 & 0.01 & 0 & 0 & 0.8 & 0 & 166 & 0.09 \\
\hline Dhonsa-3 & 0.01 & 0.11 & 607 & 0.65 & 17 & 105 & 0.09 \\
\hline Dhonsa-4 & 0 & 0.08 & 440 & 0.96 & 8 & 119 & 0.19 \\
\hline Dhonsa-5 & 0 & 0 & 0 & 0.76 & 0 & 172 & 0.19 \\
\hline Dhonsa-6 & 0 & 0 & 0 & 0.43 & 0 & 286 & 0.17 \\
\hline Dhonsa-7 & 0 & 0 & 0 & 0.56 & 0 & 171 & 0.16 \\
\hline Dhonsa-8 & 0 & 0 & 0 & 0.45 & 0 & 209 & 0.12 \\
\hline Kodki-1 & 0 & 0 & 0 & 0.44 & 0 & 164 & 0.12 \\
\hline Kodki-2 & 0 & 0 & 0 & 0.64 & 0 & 186 & 0.2 \\
\hline Kodki-3 & 0 & 0 & 0 & 0.8 & 0 & 136 & 0.18 \\
\hline Kodki-4 & 0 & 0 & 0 & 0.87 & 0 & 53 & 0.2 \\
\hline \multicolumn{8}{|c|}{ Naredi Formation, Age: Early Eocane (Ypresian) } \\
\hline NNSR-1 & 0.08 & 0.04 & 421 & 0.08 & 50 & 525 & 0.03 \\
\hline NNSR-2 & 1.41 & 24.89 & 415 & 20.46 & 122 & 81 & 0.94 \\
\hline NNSR-3 & 0.22 & 4.08 & 418 & 3.37 & 121 & 110 & 0.34 \\
\hline core 44.10 & 0.01 & 2.36 & 430 & 3.01 & 78 & 21 & 1.03 \\
\hline core 44.90 & 2.98 & 107.88 & 423 & 27.2 & 397 & 18 & 0.56 \\
\hline core 45.90 & 0.05 & 2.31 & 417 & 3.32 & 70 & 51 & 0.24 \\
\hline core 46.30 & 0.03 & 3.29 & 428 & 3.28 & 100 & 60 & 0.21 \\
\hline core 47.10 & 0.02 & 3.02 & 431 & 3.06 & 99 & 30 & 0.15 \\
\hline core 49.70 & 0.03 & 5.26 & 431 & 4.09 & 129 & 37 & 0.61 \\
\hline core 51.70 & 0.46 & 9.61 & 404 & 12.74 & 75 & 36 & 0.39 \\
\hline core 52.70 & 0.06 & 4.23 & 426 & 2.88 & 147 & 3 & 0.13 \\
\hline core 55.30 & 1.23 & 29.7 & 412 & 16.57 & 179 & 27 & 0.39 \\
\hline core 57.10 & 0.38 & 6.95 & 394 & 12.31 & 56 & 30 & 0.26 \\
\hline core 59.10 & 0.11 & 5.35 & 424 & 3.61 & 148 & 48 & 0.16 \\
\hline core 60.70 & 0.72 & 28.68 & 423 & 11.67 & 246 & 39 & 0.31 \\
\hline core 60.90 & 0.11 & 10.05 & 427 & 8.66 & 116 & 44 & 0.83 \\
\hline core 66.70 & 0.75 & 30.31 & 422 & 11.62 & 261 & 44 & 0.37 \\
\hline core 70.90 & 0.8 & 43.51 & 423 & 15.19 & 286 & 31 & 0.4 \\
\hline core 72.30 & 0.4 & 25.44 & 425 & 8.86 & 287 & 33 & 0.32 \\
\hline core 72.90 & 0.97 & 42.14 & 420 & 14.63 & 288 & 39 & 0.43 \\
\hline core 74.10 & 0.56 & 32.17 & 426 & 10.19 & 316 & 51 & 0.37 \\
\hline
\end{tabular}

signatures (Espitalié et al. 1980, 1984; Dembicki 1990). Shales from Dhonsa and Kodki region have low TOC with dominance of quartz and clay minerals, which could possibly account for the reduced amount of pyrolized hydrocarbons during the Rock-Eval pyrolysis (Mani et al. 2016). Furthermore, it is known that colour of black shale develops mainly due to the high concentration of carbonaceous matter deposited in reducing environment (Tourtelot 1979). In general, the black shale contains more than $1 \%$ of organic carbon (2$10 \%$ is the common range) (Tourtelot 1979). The shale samples collected from Dhonsa and Kodki are dark in colour. Thus, these samples might have contained more TOC during the time of deposition, but post depositional alterations could be responsible for the low TOC recorded.

Arora et al. (2015) have reported relatively higher TOC (average 1.34-3.4\%) of black shales from the Jhuran Formation (extending from Rudramata bridge to Zara village). The depositional environment of the Jhuran black shale along the northern part of mainland is suggested as shallow marine, formed during oceanic anoxia with substantial input of continental organic material (Desai et al. 2008; Arora et al. 2015). Biswas (2016) suggested the black shales of the Jhuran Formation to be prodelta deposits below the deltaic 
sandstone. However, their sampling sites are far in north from the sample locations in this study.

It is understood that the organic carbon content within the geologically old sediments does not reflect its original TOC values. Part of the initial preserved TOC may get lost within subsurface condition during diagenesis or by thermal maturation (Harwood 1982). Therefore, both of these longstanding sedimentary successions (upper Jurassic of Dhonsa and Kodki) were probably affected during the Deccan volcanism (Biswas 1987; Thakkar et al. 2006; Morino et al. 2008). We assume that sediments of these zones were uplifted and affected by severe tectonic activities. Owing to these events, sediments have lost their original TOC, either by thermal over maturation or due to oxidative weathering. This inference also helps us to explain the existence of halloysite within these areas (figure 5b). Earlier research works have shown that co-existence of halloysite with chlorite might be an indicator of formation of halloysite from chlorite either by weathering or due to thermal alteration (Cho 1992; Papoulis et al. 2009). Modeling of temperature and pressure conditions of chlorite formation using the thermodynamic approach in a closed system have shown a systematic increase in $\mathrm{Fe}^{3+}$ with decreasing temperature, which is compatible with the decrease in $a \mathrm{O}_{2}$ buffered by magnetite- or hematitechlorite equilibrium (Vidal et al. 2016). Similar temperatures are calculated for low-temperature chlorites $\left(T<300^{\circ} \mathrm{C}\right)$ using equations of semiempirical thermometers, assuming that all iron in chlorite are ferrous (Inoue et al. 2009). Formations of minerals like halloysite suggest low temperature hydrothermal origin. Thus, thermally induced alterations of organic matter pocketing these minerals are likely to occur, thereby, lowering the TOC content of these shales.

Both the NNSR and core samples belong to the Naredi Formation (Early Eocene age). The TOC values recorded in NNSR and core samples are ranging from 0.08 to $20.46 \%$ and 2.88 to $27.2 \%$ respectively (table 2). Thus, the samples from both NNSR and core are rich in organic carbon. Excellent positive correlation between $S_{1}$ and $S_{2}$ is also observed in both the sites $(R=0.99$ for NNSR and $R=0.93$ in core). Mishra et al. (2014) suggested good positive correlation between $S_{1}$ and $\mathrm{S}_{2}$ could be an indicator of common source of organic matter as well as absence of contamination. Hence, we consider that higher organic carbon in both the areas might have been derived from a common source and the samples have witnessed negligible to minimal surficial contamination. Samples of NNSR show significant presence of smectite, whereas core sediments are dominated by chlorite (figure 5c-e). Kennedy et al. (2002) observed that larger reactive surface of smectitic are capable of sorbing significant amount of organic materials from water and may be rich in organic materials. The depositional setting of the black shale in the Naredi Formation is described as coastal marsh or back swamp environment (Biswas 1992). The black shales of the Matanomadh are considered to be deposited in humid tropical climate in a reducing environment (Dutta et al. 2011). Sahay (2011) suggested that the black shales in the Panandhro lignite mine, which is situated very close to the Matanomadh area, were deposited in a brackish mangrove to freshwater swampy environment during the sea level low stand. Our investigation shows that sediments of both the studied sites contain framboidal pyrite (figure $5 \mathrm{~d}-\mathrm{f}$ ). Presence of pyrite within these samples thus indicate deposition of sediments in a highly reducing condition either in a lagoonal environment or restricted marine setting like marsh/swamp which corroborates the earlier observations (Biswas 1992; Dutta et al. 2011; Sahay 2011).

\subsection{Quality and hydrocarbon generation potentiality of organic matter in black shales}

Quality assessment of source rock in terms of kerogen type is important to infer the origin of organic matter as well as hydrocarbon generation potentiality. Sedimentary rocks having high hydrogen-carbon ratio (H:C) or high hydrogen index (HI) and low oxygen-carbon ratio $(\mathrm{O}: \mathrm{C})$ or low oxygen index (OI) values are considered as good source rock (kerogen type I and II). These types of source rocks are capable to yield oil and gas by thermal maturation. The relationship of gradually reducing HI values with an increase of OI values indicates the transformation of kerogens from type I to type IV, which has low potential to generate oil. The type III and type IV kerogens are more prone to generate coal and gas (Selley 1998; McCarthy et al. 2011). Type I kerogens are rich in lipid, usually marine or lacustrine in origin and are derived from algae, phytoplankton or strongly reworked organic matter by bacteria or microorganism. Type II kerogen is usually marine, liptinitic, formed in deep marine setting in reducing conditions from phyto and 
zooplanktons. Organic carbon in type III kerogen is derived from terrigenous organic carbon deposited in marine or other fluvial environments. Whereas type IV kerogen is the reworked organic matter formed after sub-aerial oxidation and alteration owing to weathering (Tissot and Welte 1984; North 1985; Selley 1998; McCarthy et al. 2011). Study of McCarthy et al. (2011) showed that source rocks having HI index of 50-200 are capable to generate gas, 200-300 are capable to produce gas as well as oil and above 300 may produce oil.

Samples from both Dhonsa and Kodki of the Jhuran Formation contain very low amount of TOC. In addition, these samples do not produce thermo-vaporized free hydrocarbons $\left(\mathrm{S}_{1}\right)$ and those that are liberated after cracking of organic matter $\left(\mathrm{S}_{2}\right)$ during pyrolysis (table 2). A lower HI $(\leq 28)$ and higher OI (53-286) values are shown by these samples (table 2). Thus, Rock-Eval parameters clearly suggest that they are characterized by type IV kerogen indicating no potential to generate hydrocarbon in terms of gas or oil (inert type; figures 6-7). Study of McCarthy et al. (2011) also showed that source rock having HI values $<50$ are not even gas prone. It is important to note that type III kerogen are produced from higher woody terrestrial plants whereas type IV are the oxidized, altered and recycled organic matter during earlier thermal event (North 1985; Selley 1998). Thus, the kerogens of Dhonsa and Kodki clearly indicate their terrestrial origin with exposure to previous thermal maturity events, which corroborates our earlier propositions.

The organic content is high in the samples collected from the Naredi Formation (NNSR and Matanomadh area). The organic richness of the samples are higher in NNSR area, yet two out of three samples show almost equal HI and OI values and one shows higher OI than HI indicating presence of type III and IV organic carbon (table 2; figure 6). This indicates events of alteration/oxidation of terrestrial organic carbon without any potential to generate hydrocarbons. The range of HI values (50-200) of these sediments also indicates potential to yield gas (McCarthy et al. 2011), prone to generate coal after attaining appropriate maturation.

Samples of core from the Matanomadh area show two fold distribution pattern in terms of kerogen. Sediments from 44.1 to $59.1 \mathrm{~m}$ (10 samples) show the kerogen nature restricted within type III/IV (figures 6 and 7). One sample from the depth $46.30 \mathrm{~m}$ and 6 samples within the depth 60.70-74.1 $\mathrm{m}$ belong to type II/III kerogen. One

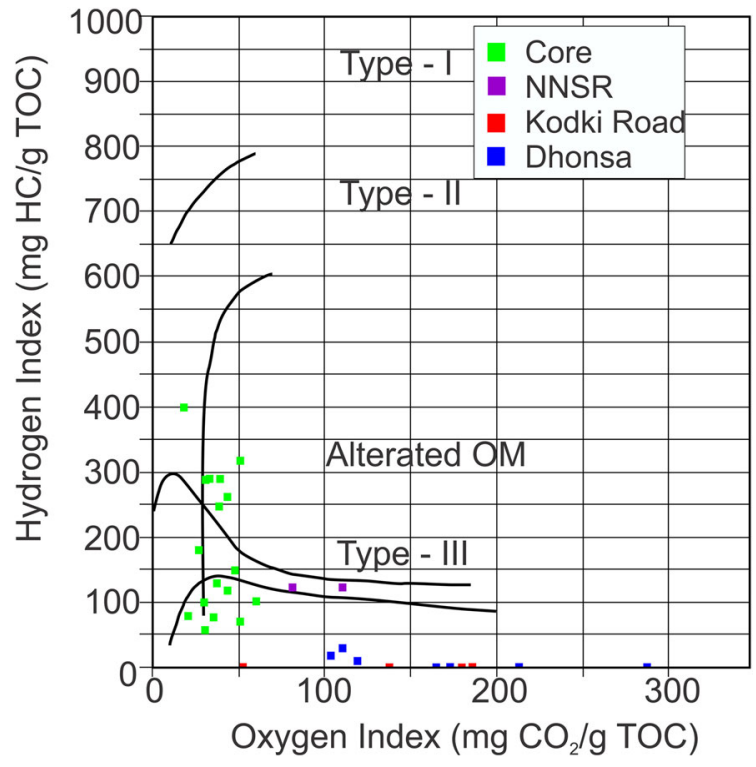

Figure 6. HI vs. OI plot indicating the kerogen type in black shales from the Kachchh basin, India.

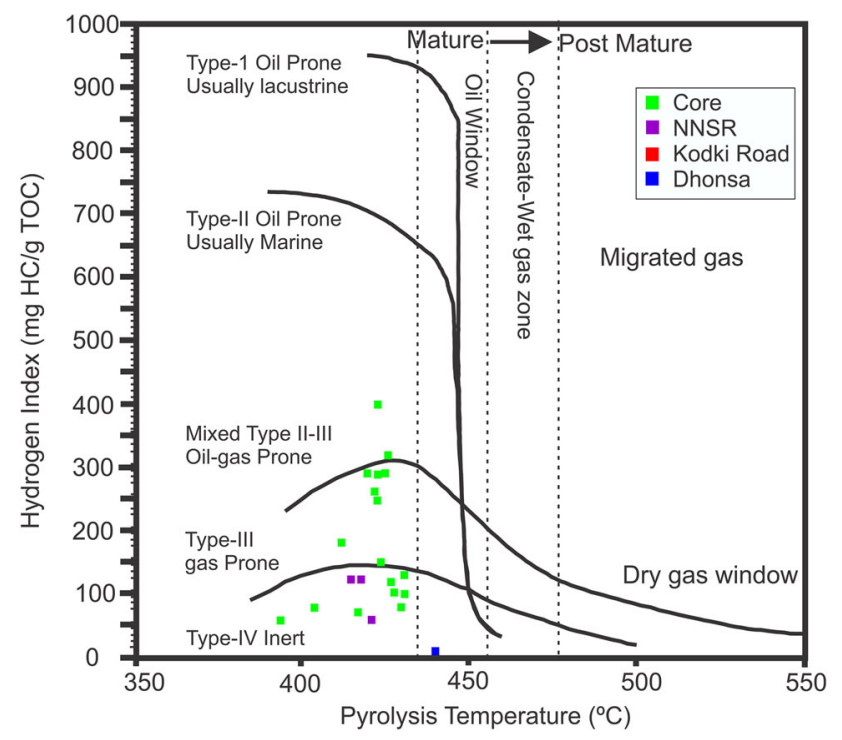

Figure 7 . HI vs. $T_{\max }$ plot indicating the thermal maturity of black shales from the Kachchh basin, India.

shale sample (at $60.9 \mathrm{~m}$ depth) belongs to type III/IV kerogen (figures 6 and 7). Thus, it is clear that the top section (44.1-59.1 m) of black shales consists of an inert type of organic matter having tendency to generate coal and gas upon suitable maturation. The lower section of the sequence (60.7-74.1 m) confirms presence of type II/III kerogen, which bears capability to generate oil and gas (table 2 ; figure 6 ). The higher $\mathrm{HI}$ values (246-316) in the lower section (table 2) also support the production capability of gas and oil (McCarthy et al. 2011). Earlier study pursued on black shales collected from subsurface mining zones 
of the Matanomadh area also show similar results with association of type II/III and samples of surface area having type III/IV kerogen (Mishra et al. 2014). The study of Dutta et al. (2011) shows shale samples in the Matanomadh mine to have type IV kerogen.

\subsection{Thermal maturity of organic carbon}

$T_{\max }$ is the temperature at which the organic carbon may yield heavy hydrocarbons after thermal cracking during pyrolysis (McCarthy et al. 2011). It is a maturity parameter and corresponds to the temperature at which maximum amount of hydrocarbons are released from the thermal degradation of kerogen, i.e., the temperature at which $\mathrm{S}_{2}$ peak reaches its maximum. $T_{\max }$ does not designate actual burial temperature of the sediments. It represents a relative value of thermal maturity and can give idea to understand the temperature requirement for thermal maturation of organic carbon (Muñez-Betelu and Baceta 1994; McCarthy et al. 2011). The higher $T_{\max }$ values $\left(440-607^{\circ} \mathrm{C}\right)$ for three black shales of the Jhuran Formation from Dhonsa and Kodki region indicate that these samples have been exposed to high temperature during the geological past (table 2; figure 7). Hence, these are in matured to post-matured stage for hydrocarbon generation. We presume that the Deccan volcanism had left some of the plutons occurring at shallow depth and contributed towards heat dissipation during later periods. This high heat flow was possibly responsible for the over maturation of kerogen. The maturation of the organic matter might be responsible for lowering its organic carbon content as inferred earlier in this work. Additionally, the $T_{\max }$ obtained may not be reliable in samples, where the value of $\mathrm{S}_{2}$ is quite low (table 2).

Relatively low $T_{\max }$ values $\left(394-431^{\circ} \mathrm{C}\right)$ are recorded for the samples of the Naredi Formation collected from NNSR and core (table 2; figure 7). The lower $T_{\max }$ values of black shales indicate that the sediments of these regions have undergone diagenesis and yet not evolved to the matured stage. It also suggests the sediments to be in early stage of maturation/oil generation. This inference corroborates the observation of Sahay (2011), which suggests that the Eocene Panandhro organic sediments have not yet suffered enough geothermal heat and remained in the immature stage. The samples may be prone to generation of oil and gas on attaining appropriate thermal maturity.

\section{Conclusions}

Organic carbon characterization of black shales from the upper Jurassic Jhuran Formation of Dhonsa and Kodki showed that organic carbons are low in concentration, marine (brackish or lagoonal), consisting of type IV organic carbon without any potential to generate hydrocarbon. Lower amount of organic matter $(<1 \%)$ is either related to thermal over-maturation due to several tectono-thermal activities that prevailed in the past in the region such as Deccan volcanism and Katrol fault or due to oxidative weathering.

Early Eocene black shales of the Naredi Formation (Naliya-Narayan Sarovar Road and core samples) are relatively rich in organic carbon, chlorite, smectite and framboidal pyrite. All these features suggest that the shale was deposited in a highly reducing lagoonal/marshy or swampy environment. These shales are characterized by immature type III and IV organic carbon, having potential to generate coal and gas after attaining suitable maturation. The upper part of core (44-59 m) bears relatively high organic carbon, which is characterized by immature, type III/IV kerogen, prone to yield coal and gas upon suitable maturation. Whereas the lower portion of the core $(60-74 \mathrm{~m})$ contains highest amount of type II/III immature organic carbon, bearing high potential to generate oil on attaining appropriate maturation.

\section{Acknowledgements}

The authors are thankful to Gaurav Chauhan (Bhuj University), D U Vyas (GM Geology) and Prhalad Singh Shaktawat (GMDC) for help in collection of samples. Hema Srivastava is thankful to the Central Research Facility of IIT(ISM) for analytical support. Authors are thankful to the anonymous reviewers for their constructive reviews and suggestions.

\section{References}

Arora A, Banerjee S and Dutta S 2015 Black shale in late Jurassic Jhuran Formation of Kachchh: Possible indicator of oceanic anoxic event?; J. Geol. Soc. India 85 265-278, https://doi.org/10.1007/s12594-015-0215-6.

Arora A, Dutta S, Gogoi B and Banerjee S 2017 The effects of igneous dike intrusion on organic geochemistry of black shale and its implications: Late Jurassic Jhuran Formation, India; Int. J. Coal Geol. 178 84-99. 
Banerjee A and Rao K L N 1993 Geochemical evaluation of part of the Cambay Basin, India; AAPG Bull. 77(1) $29-48$.

Banerjee S, Dutta S, Paikray S and Mann U 2006 Stratigraphy, sedimentology and bulk organic geochemistry of black shales from the Proterozoic Vindhyan Super group (central India); J. Earth Syst. Sci. 115(1) 37-47, https:// doi.org/10.1007/BF02703024.

Besse J and V Courtillot 1988 Paleogeographic maps of the continents bordering the Indian ocean since the Early Jurassic; J. Geophys. Res. 93(B10) 11791-11808.

Bhaskar B 2013 Energy Security and Economic Development in India: A Holistic Approach; The Energy and Resource Institute, New Delhi, India, pp. 38-42.

Biswas S K 1977 Mesozoic rock-stratigraphy of Kachchh; Quart. J. Geol. Min. Met. Soc. India 49 1-52, https:// doi.org/10.17491/cgsi/2016/105405.

Biswas S K 1987 Regional tectonic framework, structure and evolution of western marginal basins of India; Tectonophys. 135 307-327, https://doi.org/10. 1016/0040-1951(87)90115-6.

Biswas S K 1992 Tertiary Stratigraphy of Kachchh; J. Palaeontol. Soc. India 37 1-29.

Biswas S K 2005 A review of structure and tectonics of Kachchh basin, western India, with special reference to earthquakes; Curr. Sci. 88(10) 1592-1600.

Biswas S K 2016 Mesozoic and Tertiary stratigraphy of Kutch (Kachchh) - A review; Spec. Publ. Geol. Soc. India 6 1-24.

Bourah A and Ganapathi S 2015 Organic richness and gas generation potential of Permian Barren Measures from Raniganj field, West Bengal, India, India; J. Earth Syst. Sci. 124(5) 1063-1074, https://doi.org/10.1007/ s12040-015-0596-3.

Chandra K, Philip P C, Sridharan P, Chopra V S, Brahmaji Rao and Saha P K 1991 Petroleum source-rock potentials of the Cretaceous transgressive-regressive sedimentary sequences of the Cauvery Basin; $J$ Southeast Asian Earth Sci. 5(1-4) 367-371, https://doi.org/10. 1016/0743-9547(91)90050-8.

Cho H D 1992 Evidence for halloysite formation from weathering of ferruginous chlorite; Clay. Clay Miner. 40(5) 608-619.

Courtillot V, Gallet Y, Rocchia R, Feraud G, Robin E, Hofmann C, Bhandari N and Ghevariya Z G 2000 Cosmic markers, ${ }^{40} \mathrm{Ar} /{ }^{39} \mathrm{Ar}$ dating and palaeomagnetism of the KT section in the Anjar area of the Deccan large igneous province; Earth Planet. Sci. Lett. 182 137-156, https:// doi.org/10.1016/S0012-821X(00)00238-7.

Desai G B, Satish P, Shukla R and Surve D 2008 Analysis of Ichnoguilds and their Significance in Interpreting Ichnological Events: A Study from Jhuran Formation (Upper Jurassic), Western Kachchh; J. Geol. Soc. India 72 458-466.

Dembicki Jr H 1990 Mineral matrix effect during analytical pyrolysis of source rocks; Assoc. Pet. Geochem. Explor. 6 $78-105$.

DGH 2017 Directorate General of Hydrocarbons website, India (Retrieved from: http://www.ndrdgh.gov.in).

Dutta S, Mathews R P, Singh B D, Tripathi S K M, Singh A, Saraswati P K, Banerjee S and Mann U 2011 Petrology, palynology and organic geochemistry of Eocene lignite of Matanomadh, Kachchh Basin, western India: Implications to depositional environment and hydrocarbon source potential; Int. J. Coal. Geol. 85 91-102, https://doi.org/10.1016/j.coal.2010.10.003.

Espitalié J, Madec M and Tissot B 1980 Role of mineral matrix in kerogen pyrolysis: Influence on petroleum generation and migration; AAPG Bull. 64 59-66.

Espitalié J, Senga M K and Trichet J 1984 Role of the mineral matrix during kerogen pyrolysis; Org. Geochem. 6 365-382, https://doi.org/10.1016/0146-6380(84)90059-7.

Espitalié J, Deroo G and Marquis F 1986 La pyrolyse Rock-Eval et ses applications Partie 3; Rev. del'Institut Francais du Pétrole. 41 73-89, https://doi.org/10.2516/ ogst:1986003.

Harwood R J 1982 Oil and gas generation by laboratory pyrolysis of kerogen; In: Hydrocarbon Generation and source rock evaluation (Origin of Petroleum III) (eds) Cluff R M and Barrows M H, The AAPG Reprint Series 24 78-98.

Inoue A, Meunier A, Patrier-Mas P, Rigault C, Beaufort D and Vieillard P 2009 Application of chemical geothermometry to low-temperature trioctahedral chlorites; Clay. Clay Miner. 57(3) 371-382, https://doi.org/ 10.1346/CCMN.2009.0570309.

Kennedy M J, Pevear D R and Hill R J 2002 Mineral Surface Control of Organic Carbon in Black Shale; Science 295 657-660, https://doi.org/10.1126/science.1066611.

Klemme H D and Ulmishek G F 1991 Effective Petroleum Source Rocks of the World: Stratigraphic Distribution and Controlling Depositional Factors; AAPG Bull. 75 18091851.

Lafargue E, Marquis F and Pillot D 1988 Rock-Eval 6 applications in hydrocarbon exploration, production and soil contamination studies; Juillet-Août IFP. 53(4) 421-437.

Mani D, Dayal A M, Patil D J, Dayal A M, Kavita S, Hafiz M, Hakhoo N and Bhat G M 2014 Gas potential of Proterozoic and Phanerozoic shales from NW Himalaya, India: Inferences from pyrolysis; Int. J. Coal Geol. 128-129 81-95, https://doi.org/10.1016/j.coal. 2014.04.007.

Mani D, Patil D J, Dayal A M and Prasad B N 2015 Thermal maturity, source rock potential and kinetics of hydrocarbon generation in Permian shales from the Damodar Valley basin, Eastern India; Mar. Pet. Geol. 66 10561072, https://doi.org/10.1016/j.marpetgeo.2015.08.019.

Mani D, Ratnam B, Kalpana M S, Patil D J and Dayal A M 2016 Elemental and organic geochemistry of Gondwana sediments from the Krishna-Godavari Basin, India, India; Chem. Erde 76(1) 117-131, https://doi.org/10.1016/j. chemer.2016.01.002.

Mani D, Kalpana M S, Patil D J and Dayal A M 2017 Organic matter in gas shales: Origin, evolution and characterization; In: Shale gas: Exploration and environmental and economic impacts (eds) Dayal A M and Mani D, Elsevier, pp. 25-52.

Manikyamba C, Kerrich R, González-Álvarez I, Mathur R and Khanna T C 2008 Geochemistry of Paleoproterozoic black shales from the Intracontinental Cuddapah basin, India: Implications for provenance, tectonic setting, and weathering intensity; Precamb. Res. 162 424-440, https: / doi.org/10.1016/j.precamres.2007.10.003. 
McCarthy K, Niemann M, Palmowski D, Peters K and Stankiewicz A 2011 Basic petroleum geochemistry for source rock evaluation; Oilfield Rev. 23(2) 32-43.

Merh S S 1995 Geology of Gujarat; Geological Society of India, 222p.

Mishra S, Mani D, Kavitha S, Kalpana M S, Patil D J, Vyas D U and Dayal A M 2014 Organic matter characteristics and gas generation potential of the Tertiary shales from NW Kachchh, India; J. Pet. Sci. Eng. 124 114-121, https://doi.org/10.1016/j.petrol.2014.10.019.

Morino M, Malik J N, Mishra P, Bhuyan C and Kaneko F 2008 Active fault traces along Bhuj Fault and Katrol Hill Fault, and trenching survey at Wandhay, Kachchh, Gujarat, India, India; J. Earth Syst. Sci. 117(3) 181-188.

Muñez-Betelu L and Baceta J I 1994 Basics and Application of Rock-Eval/TOC Pyrolysis: An example from the uppermost Paleocene/lower most Eocene in the Basque Basin, Western Pyrenees; MUNIBE (Ciencias Naturales - Natur Zientziak) 46 43-62.

North F K 1985 Petroleum Geology; Allen \& Unwin, USA, pp. 37-68.

Paikaray S, Banerjee S and Mukherji S 2008 Geochemistry of shales from the Paleoproterozoic to Neoproterozoic Vindhyan Super group: Implications on provenance, tectonics and paleo-weathering; J. Asian Earth Sci. 32 34-48, https://doi.org/10.1016/j.jseaes.2007.10.002.

Papoulis D, Tsolis-Katagasi P, Kalampounias A G and Tsikouras B 2009 Progressive formation of halloysite from the hydrothermal alteration of biotite and the formation mechanisms of anatase in altered volcanic rocks from Limnos Island, northeast Aegean Sea, Greece, Greece; Clay. Clay Miner. 57(5) 566-577, https://doi.org/10. 1346/CCMN.2009.0570505.

Patil D J, Mani D, Madhavi T, Sudarsan V, Srikarni S, Kalpana M S, Sreenivas B and Dayal A M 2013 Near Surface isotopic and geochemical studies for hydrocarbon prospecting in Mesozoic Kutch sedimentary basin, Gujarat, Western India; J. Pet. Sci. Eng . 108 393-403, https://doi.org/10.1016/j.petrol.2013.05.002.

Peters K E and Cassa M R 1994 Applied source rock geochemistry; In: The Petroleum System from Source to
Trap (eds) Magoon L B and Dow W G, AAPG Mem. 60 93-120.

Rao G N 2001 Sedimentation, stratigraphy, and petroleum potential of Krishna-Godavari basin, East Coast of India; AAPG Bull. 85(9) 1623-1643.

Sahay V K 2011 The hydrocarbon potential, thermal maturity, sequence stratigraphic setting and depositional palaeoenvironment of carbonaceous shale and lignite successions of Panandhro, north western Kachchh Basin, Gujarat, western India; Cent. Eur. J. Geosci. 3(1) 1228, https://doi.org/10.2478/v10085-010-0032-5.

Selley R C 1998 Elements of Petroleum Geology; 2nd edn, Academic Press, pp. 191-205.

Sivan P, Datta G C and Singh R R 2008 Aromatic biomarkers as indicators of source, depositional environment, maturity and secondary migration in the oils of Cambay Basin, India; Org. Geochem. 39 1620-1630, https://doi.org/10. 1016/j.orggeochem.2008.06.009.

Tewari A, Dutta S and Sarkar T 2016 Organic geochemical characterization and shale gas potential of the Permian Barren Measures Formation, West Bokaro sub-basin, Eastern India; J. Pet. Geol. 39(1) 49-60, https://doi.org/ 10.1111/jpg.12627.

Thakkar M G, Goyal B, Patidar A K, Maurya D M and Chamyal S 2006 Bedrock gorges in the central mainland Kachchh: Implications for landscape evolution; J. Earth Syst. Sci. 115(2) 249-256, https://doi.org/10. 1007/BF02702039.

Tissot B and Welte D H 1984 Petroleum Formation and Occurrence; 2nd edn, Springer Verlag, Heidelberg, Germany, pp. 147-156.

Tourtelot H A 1979 Black Shale - Its deposition and diagenesis; Clay. Clay Miner. 27(5) 313-321.

Vidal O, Lanari P, Munoz M, Munoz M, Bourdelle F and de Andrade V 2016 Deciphering temperature, pressure and oxygen-activity conditions of chlorite formation; Clay Miner. 51 615-633, https://doi.org/10.1180/claymin. 2016.051.4.06.

Weissert H 1981 Depositional processes in an ancient pelagic environment: The Lower Cretaceous Maiolica of the southern Alps; Eclogae Geol. Helv. 74 339-352. 